\title{
Formation of Ag/Al Screen-Printing Contacts on B Emitters
}

\author{
Susanne Fritz, Markus König, Stefanie Riegel, Axel Herguth, Matthias Hörteis, and Giso Hahn, Member, IEEE
}

\begin{abstract}
In this study, the contact formation process of Al containing Ag screen-printing pastes to $\mathrm{BBr}_{3}$-based $\mathrm{B}$ emitters on $\mathrm{Si}$ is investigated. Therefore, a detailed scanning electron microscopy (SEM) and energy-dispersive $\mathrm{X}$-ray spectroscopy study of top-view and cross-sectional samples was conducted. The possible influence of a $\mathrm{SiN}_{x}: \mathrm{H}$ antireflection coating was considered by comparing contacts with and without a $\mathrm{SiN}_{x}: \mathrm{H}$ layer. To analyze the role of the glass frit in the paste, the contact formation of pastes without glass was examined. The results indicate that the $\mathrm{Ag} / \mathrm{Al}$ contact spots grow below the $\mathrm{Si}$ surface/ $\mathrm{SiN}_{x}: \mathrm{H}$ layer. The glass frit is only indispensable for etching the antireflection layer-it is not needed for melting the metal in the screen-printing paste. The realized experiments lead to a phenomenological model for the contact formation process of Al containing screen-printing pastes to boron emitters.
\end{abstract}

Index Terms-Boron emitters, contact formation, metallization, $\mathbf{p}^{+} \mathbf{S i}$, scanning electron microscopy (SEM), screen-printing.

\section{INTRODUCTION}

$\mathbf{O}$ VER the past few years, contacting $\mathrm{p}^{+}$surfaces with screen-printing metal pastes has become increasingly important for crystalline silicon-based solar cells. The performance of n-type, bifacial, and back-contact solar cells depends crucially on the quality of the electrical contact to $\mathrm{p}^{+} \mathrm{Si}$, but the development of screen-printing pastes for these purposes turned out to be challenging. Contacting $\mathrm{p}^{+} \mathrm{Si}$ with $\mathrm{Ag}$ screen-printing pastes can lead to specific contact resistances $\varrho_{\mathrm{c}}$ above $50 \mathrm{~m} \Omega$. $\mathrm{cm}^{2}$ [1]-[4], which is rather poor compared with Ag-based contacts to phosphorous-doped $\mathrm{n}^{+}$Si layers exhibiting $\varrho_{\mathrm{c}}$ typically below $5 \mathrm{~m} \Omega \cdot \mathrm{cm}^{2}$ [5]. For $\mathrm{BBr}_{3}$-based B emitters similar to the ones used in this study, a specific contact resistance above $20 \mathrm{~m} \Omega \cdot \mathrm{cm}^{2}$ has been reported [6]. The addition of Al to the paste leads to a lower $\varrho_{\mathrm{c}}$, as was first shown by Kopecek et al. [2]. A higher $\mathrm{Al}$ content in the paste results in a lower specific contact resistance [3], [7], which can be attributed to a higher density of $\mathrm{Ag} / \mathrm{Al}$ contact spots on the Si surface [7].

S. Fritz, S. Riegel, A. Herguth, and G. Hahn are with the Department of Physics, University of Konstanz, 78464 Konstanz, Germany (e-mail: susanne. fritz@uni-konstanz.de; stefanie.riegel@uni-konstanz.de; axel.herguth@unikonstanz.de; giso.hahn@uni-konstanz.de).

M. König and M. Hörteis are with the Electronic Materials Division, Business Unit Photovoltaics, Heraeus Precious Metals GmbH \& Co. KG, 63450 Hanau, Germany (e-mail: markus.koenig@heraeus.com; matthias.hoerteis@ heraeus.com).
A drawback of $\mathrm{Al}$ containing $\mathrm{Ag}$ screen-printing pastes is the observation that large $\mathrm{Ag} / \mathrm{Al}$ spikes grow into the $\mathrm{Si}$ surface that can have a depth of more than $1 \mu \mathrm{m}$ and, therefore, can penetrate the emitter. This leads to shunting of the p-n junction and deteriorates fill factor FF and open-circuit voltage $V_{\mathrm{oc}}$ and thus efficiency of the solar cell [1], [3]. In addition, higher emitter saturation current densities $j_{0 e}$ have been reported for pastes with a high $\mathrm{Al}$ content [8].

To overcome these drawbacks and to improve screen-printing pastes for contacting $\mathrm{p}^{+}$emitters, the contact formation process of Al containing Ag screen-printing pastes needs to be understood better. In the past, a lot of research has been carried out to understand the contact formation process of Ag pastes [9][12]. However, up to now, very few investigations have been carried out to understand contact formation of $\mathrm{Al}$ containing $\mathrm{Ag}$ screen-printing pastes [4], [13].

In this study, the contact formation process of $\mathrm{Al}$ containing $\mathrm{Ag}$ screen-printing pastes to $\mathrm{BBr}_{3}$ based $\mathrm{B}$ emitters is investigated systematically by scanning electron microscopy (SEM) and energy-dispersive X-ray spectroscopy (EDX) analysis. Wafers with and without $\mathrm{SiN}_{x}: \mathrm{H}$ layer are contacted with different $\mathrm{Ag} / \mathrm{Al}$ pastes. Different sample preparation techniques were applied to consider different aspects of the contacts.

\section{SAMPLE PREPARATION}

For the different experiments, $\mathrm{n}$-type $\mathrm{Cz}-\mathrm{Si}$ wafers with resistivities around $3 \Omega \mathrm{cm}$ were textured in an alkaline solution resulting in a random pyramid structure. Afterward, emitters with sheet resistances of 50 to $60 \Omega / \square$ were diffused in a $\mathrm{BBr}_{3}$-based process. Subsequently, for the experiments with a $\mathrm{SiN}_{x}: \mathrm{H}$ antireflection coating, a 75-nm-thick layer of $\mathrm{SiN}_{x}: \mathrm{H}$ was deposited onto the wafers by plasma-enhanced chemical vapor deposition. A test structure with a finger width of $200 \mu \mathrm{m}$ was screen-printed using the different $\mathrm{Al}$ containing $\mathrm{Ag}$ screenprinting pastes investigated in the respective experiments. Then, the contacts were fired under standard conditions in a belt furnace (peak temperature $\approx 800^{\circ} \mathrm{C}, \approx 2 \mathrm{~s}$ ).

For subsequent SEM and EDX analysis, samples were prepared in the same way for all experiments. For a top-view analysis of the contact area, samples were either etched back in aqua regia $\left(\mathrm{HNO}_{3}: \mathrm{HCl}, 1: 3\right)$ to remove only the bulk metal or in hydrofluoric acid (HF, 5\%) to remove the glass layer as well. For a cross-sectional view, the different samples were treated with focused ion beam (FIB). As FIB cross sections are limited to small areas, in addition mechanically polished cross sections of the whole contact profile are investigated. 
TABLE I

Characteristics of EXAmined Ag/Al SCREEN-Printing PASTES

\begin{tabular}{lcc}
\hline \hline Paste & Al CONTENT & $\varrho_{\mathrm{c}}\left(\mathrm{m} \Omega \cdot \mathrm{cm}^{2}\right)$ \\
\hline $\mathrm{L}$ & low & $7.76 \pm 2.63$ \\
$\mathrm{H}$ & high & $2.08 \pm 0.55$ \\
\hline \hline
\end{tabular}

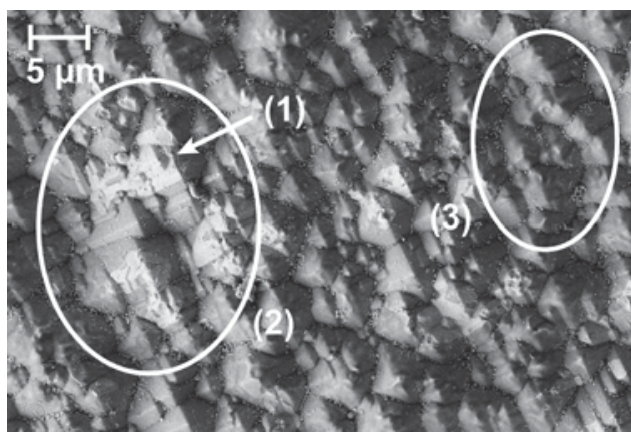

Fig. 1. SEM micrograph of a sample etched in HF. Close to the $\mathrm{Ag} / \mathrm{Al}$ contact spots (1) the pyramids are sharp-edged, indicating that they are not etched by the glass frit (2). Further away from the spots, the pyramids are corroded by the glass frit (3).

\section{EXPERIMENTAL DETAILS}

\section{A. Ag Screen-Printing Pastes With Different Al Content}

For this experiment, two experimental Al containing $\mathrm{Ag}$ screen-printing pastes with different $\mathrm{Al}$ content (see Table I) were screen-printed on Si wafers with a $50 \Omega / \square$ B emitter and a $\mathrm{SiN}_{\mathrm{x}}: \mathrm{H}$ antireflection coating. After firing, $\varrho_{\mathrm{c}}$ was determined by transfer length method (TLM) measurements. Afterward, samples were prepared for SEM analysis.

\section{1) Specific Contact Resistance and Top-View Analysis}

The specific contact resistance of the paste with a low $\mathrm{Al}$ content (referred to as paste L) was $\varrho_{\mathrm{c}}=7.8 \pm 2.6 \mathrm{~m} \Omega \mathrm{cm}^{2}$ for the paste with a high $\mathrm{Al}$ content (paste $\mathrm{H}$ ) $\varrho_{\mathrm{c}}=2.1 \pm 0.6$ was determined. The characteristics of the two used screen-printing pastes are summarized in Table I.

A typical top-view SEM micrograph of samples etched back in HF is shown in Fig. 1. By EDX analysis, the white pyramids (1) are identified as $\mathrm{Ag} / \mathrm{Al}$ contact spots grown in the Si surface. On samples contacted with paste $\mathrm{H}$, a higher density of $\mathrm{Ag} / \mathrm{Al}$ contact spots can be found than on samples contacted with paste $\mathrm{L}$. Therefore, it can be concluded that a higher $\mathrm{Al}$ content in the screen-printing paste results in a higher density of $\mathrm{Ag} / \mathrm{Al}$ contact spots on the Si surface, leading to a lower specific contact resistance, as was reported by Seyedmohammadi et al. [7].

Additionally, samples etched in aqua regia were analyzed (see Fig. 2). The holes in the glass layer (3), where only $\mathrm{Si}$ is detected, have the shape of inverted pyramids and correspond to etched back Ag/Al contact spots. Apart from the number of holes in the glass layer, the micrographs look identical for both pastes. The removal of the $\mathrm{Ag} / \mathrm{Al}$ in the contact spots by aqua regia indicates a direct connection between the contact spots and the bulk metal of the contact finger with no glass interlayer.

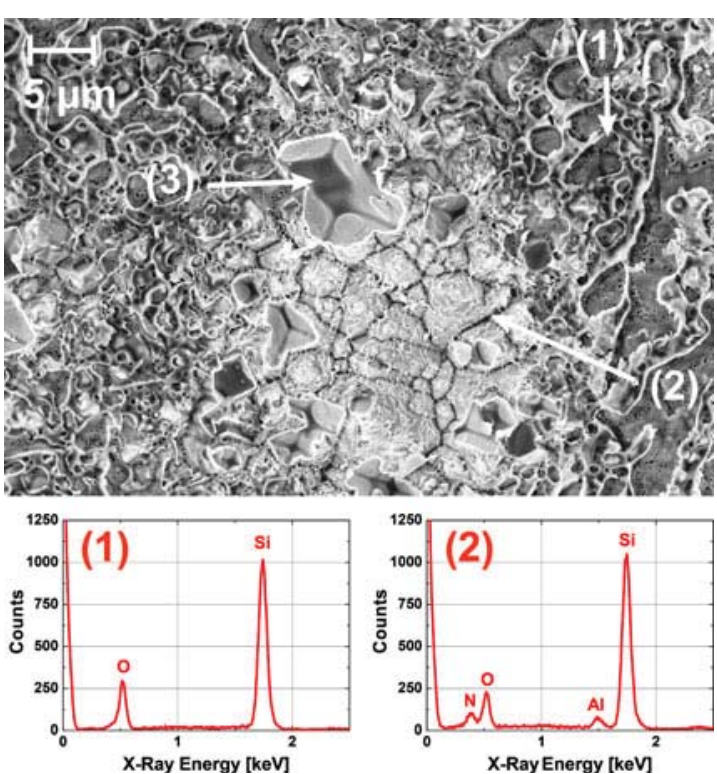

Fig. 2. SEM micrograph and EDX spectra of a sample etched in aqua regia. At bright glass areas (2), $\mathrm{N}$ and $\mathrm{Al}$ can be detected by EDX measurements. These areas surround $\mathrm{Si}$ spots (3). The dark glass regions, e.g., (1), do not feature significant amounts of $\mathrm{N}$ or $\mathrm{Al}$.

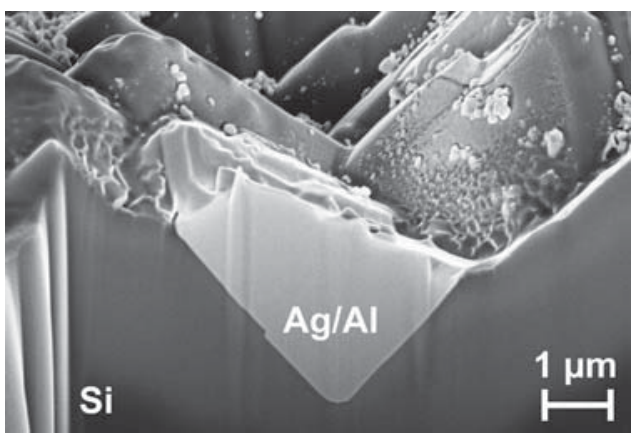

Fig. 3. FIB cross section of contact spot. The shape of an inverted pyramid can clearly be seen.

\section{2) Focused Ion Beam Cross Sections and Al Content of Contact Spots}

In Fig. 3, an FIB cross section of an $\mathrm{Ag} / \mathrm{Al}$ contact spot on an HF etched sample is shown. It can be clearly seen that the contact spots grow into the Si surface in the shape of an inverted pyramid. The interfaces between the $\mathrm{Si}$ and the metal correspond to the (111) planes of the Si crystal. To check if different $\mathrm{Al}$ contents in an Ag screen-printing paste lead to different $\mathrm{Al}$ contents in the $\mathrm{Ag} / \mathrm{Al}$ contact spots, EDX measurements were conducted at FIB cross sections of the different samples. Independent of the $\mathrm{Al}$ fraction in the paste, the $\mathrm{Al}$ content of the contact spots is in the range of 3-10 at\%.

\section{3) Analysis of Polished Cross Sections}

For a cross-sectional analysis of the whole contact finger, polished cross sections were prepared. In Fig. 4, a part of a contact finger is shown. The dark spheres (1) in the bulk contact can be identified as pure Al particles. These particles did not 


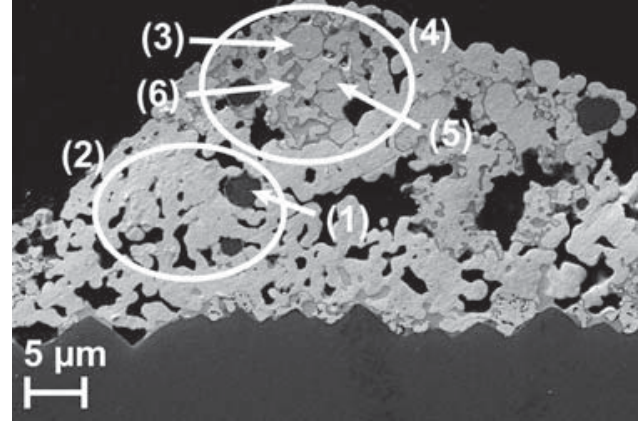

Fig. 4. Polished cross section of an $\mathrm{Ag} / \mathrm{Al}$ contact finger. In the part of the contact with homogeneous microstructure (2), only intact Al particles (1) can be found. The bright spheres (3) and the bright areas (5) in the inhomogeneous part of the finger (4) consist of an $\mathrm{Ag} / \mathrm{Al}$ phase. The darker areas (6) in the inhomogeneous structured part of the finger (4) are composed of Al containing glass.

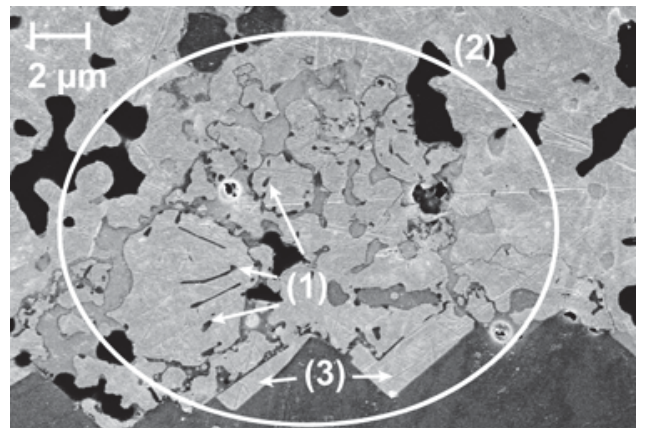

Fig. 5. Polished cross section of an Ag/Al contact finger. The dark lines and spots (1) in the inhomogeneous part of the finger (2) consist of Si. Below this part of the finger, $\mathrm{Ag} / \mathrm{Al}$ contact spots in the shape of inverted pyramids (3) are located.

merge with the surrounding in the firing process. Around the intact $\mathrm{Al}$ particles, the homogeneous microstructure (2) consists of an Ag phase with some pores. In addition to the intact $\mathrm{Al}$ particles (1), bright spheres (3) can be distinguished. They are embedded in an inhomogeneous microstructure (4) with a bright and a darker component. The bright spheres (3) and the bright component (5) turn out to be an Ag/Al phase. The darker part (6) is an Al containing glass. In regions with the inhomogeneous microstructure, the Al particles have melted and merged with the Ag and the glass.

Fig. 5 shows a cross-sectional SEM micrograph of the Simetal interface. The Ag/Al contact spots in shape of inverted pyramids (3) can clearly be recognized. Above the contact spots, the contact finger shows the inhomogeneous $\mathrm{Al}$ containing microstructure described above. No contact spots can be found below homogeneous finger regions that only contain Ag.

\section{B. Silicon Diffusion}

In the firing process, $\mathrm{Ag} / \mathrm{Al}$ contact spots grow into the $\mathrm{Si}$ surface. The question arises where the dissolved Si remains. Therefore, samples of the previous experiment were further analyzed regarding the question of the whereabouts of the Si. In Fig. 5, besides the Ag/Al contact spots (3) and the inhomo-

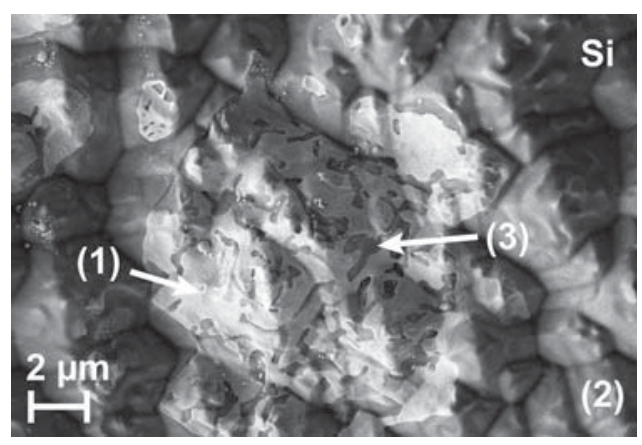

Fig. 6. Top-view SEM micrograph of a sample without $\mathrm{SiN}_{\mathrm{x}}: \mathrm{H}$ layer. The $\mathrm{Ag} / \mathrm{Al}$ contact spots (1) do not have the shape of sharp pyramids and the $\mathrm{Si}$ pyramids close to the contact spots are corroded (2). In the contact spots, $\mathrm{Si}$ spots can be distinguished (3).

geneous structured finger regions (2), dark lines and spots (1) can be recognized in the $\mathrm{Ag} / \mathrm{Al}$ phase of the contact finger. In these structures, a high amount of Si can be detected by EDX, whereas the $\mathrm{Ag} / \mathrm{Al}$ phase around the dark spots contains almost no $\mathrm{Si}$. The $\mathrm{Si}$ containing structures have a width in the range of $200 \mathrm{~nm}$. As the spatial resolution of the EDX measurement is $>500 \mathrm{~nm}$, it cannot be confirmed for sure that the structures consist of pure Si. Nonetheless, it can be concluded that in the firing process, the dissolved $\mathrm{Si}$ at the Si surface diffuses into the bulk finger, where it precipitates when the silicon concentration drops below the solubility limit while the wafers cool down.

\section{Influence of $\operatorname{SiN}_{x}: H$ Layer}

To investigate the influence of a $\operatorname{SiN}_{x}: \mathrm{H}$ layer in the contact formation process, $\mathrm{Si}$ wafers with and without $\mathrm{SiN}_{x}: \mathrm{H}$ antireflection coating are compared. All wafers received a $50 \Omega / \square$ $\mathrm{BBr}_{3}$-based emitter and were screen-printed with the same experimental Al containing Ag paste.

As described before, Fig. 1 shows a top-view SEM micrograph of an HF-etched contact on a $\mathrm{SiN}_{x}: \mathrm{H}$-covered Si surface. Close to the described $\mathrm{Ag} / \mathrm{Al}$ contact spots, the Si surface consists of sharp pyramids, indicating that the surface was not affected by the glass frit. Further away from the contact spots, the pyramids are corroded as a result of etching by the glass frit.

Fig. 6 shows a top view of a sample prepared identically but without $\mathrm{SiN}_{x}: \mathrm{H}$. The $\mathrm{Ag} / \mathrm{Al}$ contact spots (1) no longer have the shape of sharp pyramids. The Si surface is corroded by the glass frit all over the contact area and close to the contact spots (2). In some contact spots, Si spots can be distinguished (3). In Fig. 2 (sample with $\mathrm{SiN}_{x}: \mathrm{H}$, etched in aqua regia), it is conspicuous that two different glass regions can be distinguished. The glass layer around the sites of the contact spots, corresponding to the regions with sharp-edged pyramids on the HF etched samples, shows a bright aspect and is thin, as the Si pyramids can be seen through the glass. EDX measurements reveal the presence of $\mathrm{N}$ and $\mathrm{Al}$ (see the EDX spectrum on the right-hand side of Fig. 2). In further distance to the contact spots, the glass looks darker and seems to be thicker. No $\mathrm{N}$ and $\mathrm{Al}$ can be detected. These regions correspond to the positions with corroded pyramids on the HF-etched surfaces. For the samples without a $\operatorname{SiN}_{x}: H$ layer, 


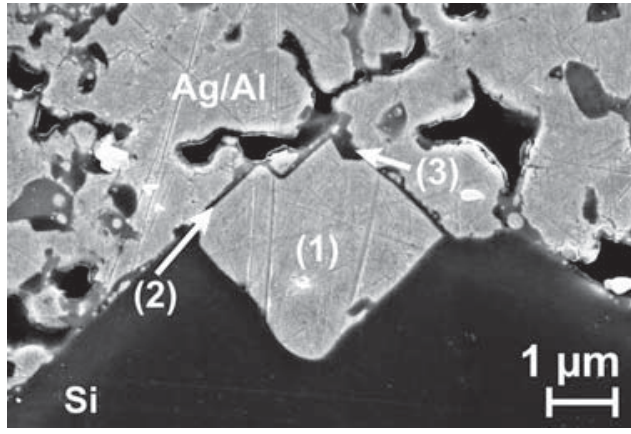

Fig. 7. Polished cross section of sample with $\mathrm{SiN}_{x}: \mathrm{H}$ layer. The intermediate layer (2) between the Ag/Al contact spot (1) follows the former Si surface. On top of the contact spot, Si residues can be found (3).

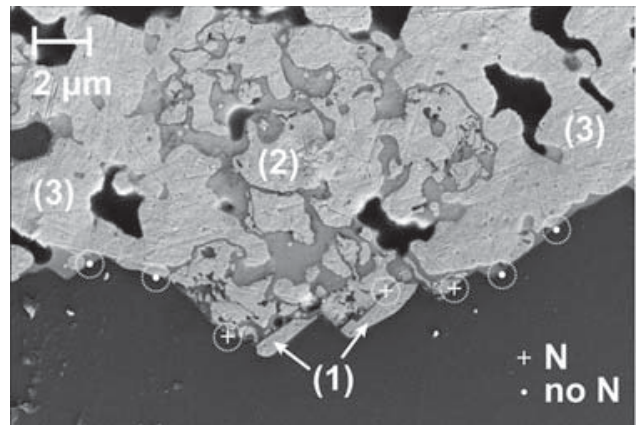

Fig. 8. Cross section of a screen printed contact. Above the Ag/Al contact spots (1), the contact microstructure is inhomogeneous (2). $\mathrm{N}$ is detected by EDX measurements above the contact spots and below the inhomogeneous regions (crosses). Below the homogeneous part of the contact (3), no $\mathrm{N}$ is detected (points). The dashed circles indicate the excitation region of the electron beam for EDX measurements.

the bulk silver could not be removed by aqua regia. Therefore, samples were etched in $\mathrm{NH}_{3}: \mathrm{H}_{2} \mathrm{O}_{2}$. The glass structure looks similar over the whole contact area. It has a different structure compared with the samples with $\mathrm{SiN}_{x}: \mathrm{H}$ layer. As this was also observed in earlier experiments without $\mathrm{SiN}_{x}: \mathrm{H}$, this difference in the glass structure is not expected to be caused by the different etching techniques.

Fig. 7 shows a polished cross section of an $\mathrm{Ag} / \mathrm{Al}$ contact spot on a sample with $\mathrm{SiN}_{x}: \mathrm{H}$ layer. Between the contact spot grown into the former Si surface (1) and the bulk contact above, a thin layer can be seen (2). This intermediate layer follows the shape of the Si pyramids of the surface texture. On the left side, it can be clearly seen that it continues the orientation of the Si surface. The pyramidal shape of the contact spots in top-view pictures can, therefore, be confirmed. The thickness of the intermediate layer lies between 30 and $80 \mathrm{~nm}$. EDX measurements reveal the presence of $\mathrm{N}$. Therefore, it can probably be identified as a residual $\mathrm{SiN}_{x}: \mathrm{H}$ layer. However, as the excitation region of the electron beam is larger than the thickness of the layer, it cannot be confirmed for sure that the $\mathrm{N}$ originates from this layer. Nonetheless, it is concluded that at least part of the $\operatorname{SiN}_{x}: H$ layer is most likely not etched away by the glass frit below inhomogeneous structured parts of the finger. On the right side, on top of the contact spot, remains of Si can be found (3).

In Fig. 8, a larger section of the metal-Si interface is shown. $\mathrm{N}$ can be detected directly above the contact spots and between

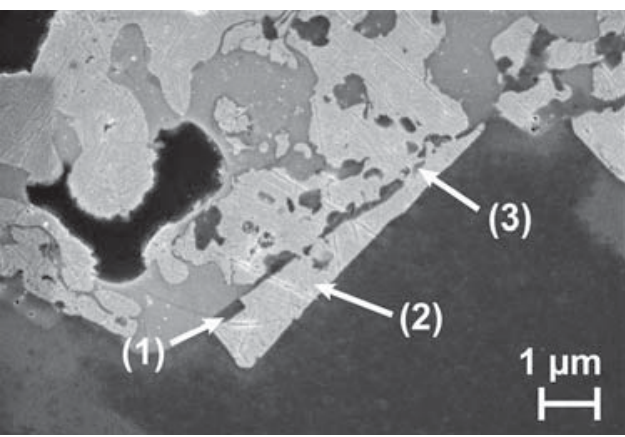

Fig. 9. Polished cross section of a sample without an $\mathrm{SiN}_{x}: \mathrm{H}$ layer. The $\mathrm{Ag} / \mathrm{Al}$ contact spot (2) is connected to the bulk contact on small connection points (3). Above the contact spot, Si residues can be found (1).

the $\mathrm{Si}$ and the inhomogeneous part of the bulk finger close to the contact spots, as indicated by crosses. Between the homogeneous part of the contact finger and the Si surface, no N can be detected (points).

Without $\mathrm{SiN}_{x}: \mathrm{H}$, the situation is different, as can be seen in Fig. 9. In this case, no intermediate layer can be distinguished, and the surface of the contact spots does not show the pyramidal topology of the former Si surface, as was observed in the topview pictures (cf., Fig. 6). In some cases, Si residues (1) can be found above the contact spots (2). The connection between the contact spot and the bulk contact is limited to small areas (3). In other cases, the contact spots are directly connected to the bulk metal on the full area of the contact spot. No $\mathrm{N}$ can be detected at any part of the Si-metal or metal-bulk contact interface.

In top-view analysis, as well as in cross-sectional ones, $\mathrm{N}$ can only be detected on samples with a $\operatorname{SiN}_{x}: \mathrm{H}$ layer. Therefore, it is concluded that the $\mathrm{N}$ is a residue of the antireflection coating.

At some contact spots, Si remains can be found between the contact spot and the bulk contact on samples with or without $\operatorname{SiN}_{x}: \mathrm{H}$.

\section{Influence of the Glass Frit}

A fundamental role of the glass frit in the contact formation process is to etch the antireflection coating and, therefore, enable the growth of contact spots on the Si surface. Additionally, for $\mathrm{Ag}$ screen-printing pastes on $\mathrm{P}$ emitters, the glass frit and/or $\mathrm{Pb}$ in the glass is needed to melt the $\mathrm{Ag}$ at temperatures below the eutectic temperature of the $\mathrm{Ag}-\mathrm{Si}$ system $\left(836^{\circ} \mathrm{C}\right)$ and allow $\mathrm{Ag}$ crystal growth [10]. Therefore, the question arises whether the role of the glass frit and/or $\mathrm{Pb}$ is similar for $\mathrm{Al}$ containing $\mathrm{Ag}$ screen-printing pastes. The glass components could influence the contact formation process by reacting or mixing with the $\mathrm{Ag}$ or Al, and the glass could be required to break the oxide shell of the Al particles in the paste. To eliminate the possible influence of the glass, an Al containing Ag screen-printing paste free of glass frit was used. The paste was screen-printed on Si wafers with a $60 \Omega / \square \mathrm{BBr}_{3}$-based emitter with and without $\mathrm{SiN}_{x}: \mathrm{H}$ antireflection coating.

1) Specific Contact Resistance and Top-View Analysis: TLM measurements were performed to ensure that a measurable electrical contact between $\mathrm{Si}$ and metal was formed in the firing 


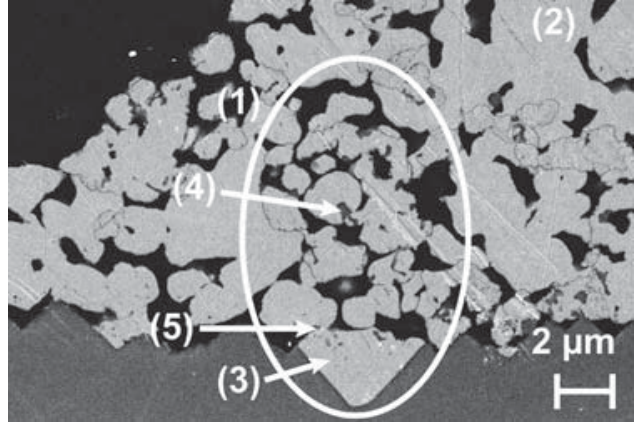

Fig. 10. Polished cross section of a sample printed with paste without glass frit. Above the Ag/Al contact spot (3), the Ag/Al phase (1) with Si accumulations (4) shows a different microstructure from the pure Ag (2). The direct contact between the $\mathrm{Ag} / \mathrm{Al}$ contact spot and the bulk metal is reduced on small points of contact (5).

process. For samples with antireflection layer, contact resistance was too high to be reasonably measured. Samples without $\mathrm{SiN}_{x}: \mathrm{H}$ layer yield a specific contact resistance of $\varrho_{\mathrm{c}}=3.3 \pm$ $1.3 \mathrm{~m} \Omega \mathrm{cm}^{2}$. On wafers with $\mathrm{SiN}_{x}: \mathrm{H}$ layer, Ag screen-printing pastes with glass frit and a varying $\mathrm{Al}$ content show specific contact resistances between 4.5 and $0.86 \mathrm{~m} \Omega \mathrm{cm}^{2}$.

A top-view SEM analysis of samples etched in aqua regia shows no holes in shape of inverted pyramids on samples with $\mathrm{SiN}_{x}: \mathrm{H}$ layer. This result was expected, as an intact antireflection layer prevents a direct contact between metal and $\mathrm{Si}$, and thus, material exchange is impeded.

For the case without $\mathrm{SiN}_{x}: \mathrm{H}$ layer, marks of former $\mathrm{Ag} / \mathrm{Al}$ contact spots can be found all over the contact area. This observation can explain the measured contact resistances.

2) Analysis of Polished Cross Sections: To get a deeper insight into the contact formation process without glass frit, polished cross sections were prepared.

In both cases-with and without $\operatorname{SiN}_{x}: \mathrm{H}$ layer-only few intact $\mathrm{Al}$ particles can be found in the metal finger after firing. Most Al particles have melted and mixed with the surrounding Ag. Fig. 10 shows a cross section of a sample without $\operatorname{SiN}_{x}: H$. The formed Ag/Al phase (1) can again be distinguished from the pure $\mathrm{Ag}$ (2) by a different microstructure with dark lines. $\mathrm{Si}$ accumulations can be found in this part of the finger (4). Focusing on the metal-Si interface, again $\mathrm{Ag} / \mathrm{Al}$ contact spots (3) can only be found below the Ag/Al phase. The direct contact between the $\mathrm{Ag} / \mathrm{Al}$ contact spot and the bulk metal is reduced on small points of contact (5) due to the porous structure of the finger. As mentioned before, for samples with an antireflection layer, no $\mathrm{Ag} / \mathrm{Al}$ contact spots can be found on the Si surface as the $\mathrm{SiN}_{x}: \mathrm{H}$ layer prevents contact formation, even if the $\mathrm{Ag} / \mathrm{Al}$ phase is close to the Si surface.

\section{DISCUSSION AND MODEL FOR CONTACT FORMATION}

In the firing process, the $\mathrm{Al}$ particles in the contact finger melt at temperatures above $660{ }^{\circ} \mathrm{C}$. The $\mathrm{Al}$ starts dissolving the surrounding $\mathrm{Ag}$ and an $\mathrm{Ag} / \mathrm{Al}$ phase is formed. Additionally, the $\mathrm{Al}$ mixes with the glass close to the molten particle. An inhomogeneous contact structure forms (see (4) in Fig. 4). During

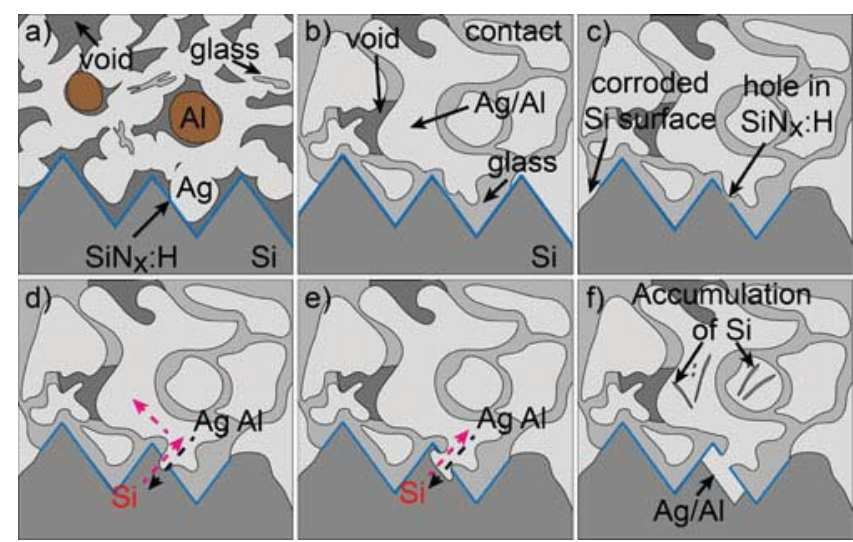

Fig. 11. Schematic of the process of contact formation.

the firing process, more $\mathrm{Ag}$ is dissolved, and the fraction of $\mathrm{Ag}$ in the $\mathrm{Ag} / \mathrm{Al}$ phase grows.

If these inhomogeneous parts of the contact get in contact with the $\mathrm{Si}$ surface, $\mathrm{Si}$ is dissolved, and the exchange of Si from the surface to the bulk finger and of $\mathrm{Ag}$ and $\mathrm{Al}$ from the finger into the former Si bulk can occur. Therefore, the more Al particles are present in the paste, the higher the density of inhomogeneous regions, and the higher the probability that these regions are in contact with the Si surface and contact spots are formed. This explains the lower specific contact resistance for the paste with higher $\mathrm{Al}$ content. However, this argumentation is only valid for pastes with the same size distribution of the $\mathrm{Al}$ particles.

For wafers with $\mathrm{SiN}_{x}: \mathrm{H}$ coating, a residual $\mathrm{SiN}_{x}: \mathrm{H}$ layer can be found below the inhomogeneous finger parts and above the $\mathrm{Ag} / \mathrm{Al}$ contact spots (see Fig. 8). For wafers with and without antireflection coating, Si residues can be observed between the contact spot and the bulk contact (see Figs. 7 and 9). Therefore, it is concluded that the material exchange does not take part on the whole area of the final contact spot. In case of a $\operatorname{SiN}_{x}: H$ layer, the exchange occurs through holes in the layer and without $\mathrm{SiN}_{x}: \mathrm{H}$ in small points of contact between the bulk metal and the forming contact spot.

The presented investigations suggest that in contrast with Ag screen-printing pastes [10], the glass or its components (like $\mathrm{Pb}$ ) are not needed for dissolving the metal, as an $\mathrm{Ag} / \mathrm{Al}$ phase can also be observed for the screen-printing paste without glass frit [see Fig. 10]. For the contact formation of Al containing $\mathrm{Ag}$ screen-printing pastes, the role of the glass frit seems to be limited to etching the antireflection coating.

\section{1) Model for Contact Formation}

The observations introduced in this paper can be summarized in a first model for the contact formation of $\mathrm{Al}$ containing $\mathrm{Ag}$ screen-printing pastes to boron emitters. A schematic of the model is shown in Fig. 11.

a) After drying and before the firing process, the wafers have an intact $\mathrm{Si}$ surface/ $\mathrm{SiN}_{x}: \mathrm{H}$ layer (no visible damage). The contact has a porous structure and consists of pure $\mathrm{Al}$ 
particles in an oxide shell, elementary Ag, glass frit, and residues of organics, which are not further observed here.

b) In the firing process, the $\mathrm{Al}$ particles in the paste melt at temperatures above $660{ }^{\circ} \mathrm{C}$. Gradually, the adjacent $\mathrm{Ag}$ is dissolved and mixes with the $\mathrm{Al}$, building an $\mathrm{Ag} / \mathrm{Al}$ phase. Part of the $\mathrm{Al}$ also mixes with the glass close to the former Al particle. The glass itself or its components have no apparent influence on the formation of the $\mathrm{Ag} / \mathrm{Al}$ phase. An inhomogeneous microstructure forms in this part of the contact. At these temperatures the glass frit already etches the $\mathrm{SiN}_{x}: \mathrm{H}$ layer or $\mathrm{Si}$, respectively [9].

c) More $\mathrm{Ag}$ is dissolved, increasing the $\mathrm{Ag}$ fraction in the $\mathrm{Ag} / \mathrm{Al}$ phase. The glass frit further etches the $\mathrm{SiN}_{x}: \mathrm{H} / \mathrm{Si}$ surface. Below homogeneous parts of the finger without $\mathrm{Al}$, the entire surface is etched-the $\mathrm{SiN}_{x}: \mathrm{H}$ layer is totally removed and/or the Si pyramids are corroded. Below the inhomogeneous finger regions with $\mathrm{Al}$, the glass etches the surface more slowly. The $\mathrm{SiN}_{x}: \mathrm{H}$ layer is only removed completely at small spots, leaving holes in the layer. The Si pyramids remain sharp.

d) Below the inhomogeneous parts of the finger, the exchange of $\mathrm{Si}$ into the bulk contact and $\mathrm{Ag} / \mathrm{Al}$ under the former $\mathrm{Si}$ surface starts through holes in the $\mathrm{SiN}_{x}: \mathrm{H}$ layer. For wafers without antireflection coating, the exchange occurs on small points of contact between the forming contact spot and the bulk finger.

e) The exchange of $\mathrm{Si}$ and $\mathrm{Ag} / \mathrm{Al}$ goes on. As the exchange is limited to a small area, the $\mathrm{Ag} / \mathrm{Al}$ contact spots form below the $\mathrm{SiN}_{x}: \mathrm{H}$ layer and/or Si surface. They grow in the shape of inverted pyramids with (111) facets into the Si.

f) While the wafers cool down, Si accumulates in small spots. The Ag/Al contact spots solidify.

\section{2) Application of the Model on Different Systems}

In the following, the introduced model is applied to different systems. Wafers with and without $\mathrm{SiN}_{x}: \mathrm{H}$ layer are considered, as are pastes with and without glass frit.

1) $\operatorname{SiN}_{x}: H$, paste with glass frit: The model was already applied to this case in the previous section.

2) No SiN $\mathrm{N}_{x}: \mathrm{H}$, paste with glass frit: At $660^{\circ} \mathrm{C}$, the $\mathrm{Al}$ starts to melt and mixes with the $\mathrm{Ag}$ and the glass forming an inhomogeneous microstructure. The formed $\mathrm{Ag} / \mathrm{Al}$ phase gets in contact with the Si surface. The direct contact is reduced to a small area, as glass and pores can be located between the Si surface and the bulk metal (see Fig. 9). The exchange of $\mathrm{Si}$ into the finger and of $\mathrm{Ag}$ and $\mathrm{Al}$ into the $\mathrm{Si}$ occurs through these small points of contact [see Fig. 9, (3)]. The Ag/Al contact spots grow below the Si surface. Therefore, after cooling down, Si residues can be found between the $\mathrm{Ag} / \mathrm{Al}$ contact spots and the contact finger for some contact spots (1). The dissolved Si can be found in $\mathrm{Si}$ accumulations in the contact finger.

3) $\operatorname{SiN}_{x}: H$, paste without glass frit: At $660^{\circ} \mathrm{C}$, the $\mathrm{Al}$ particles start to melt and mix with the surrounding Ag forming an $\mathrm{Ag} / \mathrm{Al}$ phase. As the $\mathrm{SiN}_{x}: \mathrm{H}$ layer is not etched away by glass frit, the $\mathrm{Ag} / \mathrm{Al}$ phase has no direct contact with the Si surface. Therefore, no material exchange occurs, and no contact spots form on the Si surface.

4) No SiN $\mathrm{N}_{x}: H$, paste without glass frit: The Al particles melt at temperatures above $660^{\circ} \mathrm{C}$ as in the previous case. The formed $\mathrm{Ag} / \mathrm{Al}$ phase gets in contact with the Si surface on small points of contact [see (5) in Fig. 10] due to the porous structure of the finger. Because no $\operatorname{SiN}_{x}: H$ layer was deposited, no glass frit is needed to realize a direct contact between the Ag/Al phase and the Si. As in the case of the paste with glass frit but without $\mathrm{SiN}_{x}: \mathrm{H}$ layer, the $\mathrm{Ag} / \mathrm{Al}$ contact spot forms below the Si surface and the solved $\mathrm{Si}$ can be found in $\mathrm{Si}$ accumulations in the contact finger.

\section{CONCLUSION}

A detailed SEM and EDX analysis of different $\mathrm{Ag} / \mathrm{Al}$ pastes screen-printed on highly B doped Si has been conducted. The results have been summarized in a model of contact formation of Al containing Ag screen-printing pastes. The introduced model was then applied to explain the contact formation process of different systems with $\mathrm{Al}$ containing Ag screen-printing pastes. $\mathrm{Al}$ particles in the paste melt at temperatures above $660{ }^{\circ} \mathrm{C}$, dissolve the surrounding Ag, and mix with the glass frit. An inhomogeneous microstructure forms. At sites where the Al containing parts of the finger get in contact with the Si surface, $\mathrm{Ag} / \mathrm{Al}$ contact spots form. For Al containing pastes, the role of the glass frit seems to be reduced to etching of the $\mathrm{SiN}_{x}: \mathrm{H}$ layer. The glass or its components (like $\mathrm{Pb}$ ) are not needed for melting the Ag or Ag transport to the Si surface, as a contact was also formed for the paste without glass frit.

\section{REFERENCES}

[1] R. Lago, L. Pérez, H. Kerp, I. Freire, I. Hoces, N. Azkona, F. Recart, and J. C. Jimeno, "Screen printing metallization of boron emitters," Prog. Photovoltaic, Res. Appl., vol. 18, pp. 20-27, 2010.

[2] R. Kopecek, T. Buck, J. Libal, R. Petres, I. Röver, K. Wambach, R. Kinderman, L. J. Geerligs, and P. Fath, "Large area n-type multicrystalline silicon solar cells with B-emitter: Efficiencies exceeding 14\%," in Proc. 15th Int. Photovoltaic Sci. Eng. Conf., 2005, pp. 892-894.

[3] H. Kerp, S. Kim, R. Lago, F. Recart, I. Freire, L. Pérez, K. Albertsen, J. C. Jiméno, and A. Shaikh, "Development of screen printable contacts for $\mathrm{p}^{+}$emitters in bifacial solar cells," in Proc. 21st Eur. Photovoltaic Sol. Energy Conf., 2006, pp. 892-894.

[4] S. Riegel, F. Mutter, G. Hahn, and B. Terheiden, "Contact formation in the silver/aluminum thick film firing process: A phenomenological approach," in Proc. 25th Eur. Photovoltaic Sol. Energy Conf., 2010, pp. 2353-2356.

[5] E. Cabrera, S. Olibet, D. Rudolph, E. Wefringhaus, R. Kopecek, D. Reinke, and G. Schubert, "Influence of surface topography on the glass coverage in the contact formation of silver screen-printed Si solar cells," IEEE J. Photovoltaics, vol. 3, no. 1, pp. 102-107, Jan. 2013.

[6] S. Fritz, S. Riegel, S. Gloger, D. Kohler, M. König, M. Hörteis, and G. Hahn, "Influence of emitter properties on contact formation to $\mathrm{p}^{+}$silicon," Energy Procedia, vol. 38, pp. 720-724, 2013.

[7] S. Seyedmohammadi, E. Graddy, and A. Shaik, "Screen printable Ag-Al metal pastes for $\mathrm{p}^{+}$silicon application in solar cells," in Proc. 35th IEEE Photovoltaic Spec. Conf., 2010, pp. 3600-0603.

[8] Y.-W. Ok, A. D. Upadhyaya, F. Zimbardi, Y. Tao, I. B. Cooper, A. Rohatgi, A. F. Carroll, and T. Suess, "Effect of Al content on the performance of Ag/Al screen printed n-type Si Solar cells," in Proc. 39th IEEE Photovoltaic Spec. Conf., 2013, pp. 2247-2249.

[9] G. Schubert, "Thick film metallization of crystalline silicon solar cells: Mechanisms, models and applications," Ph.D. dissertation, Department of Physics, Univ. Konstanz, Konstanz, Germany, 2006. 
[10] G. Schubert, B. Fischer, and P. Fath, "Formation and nature of Ag thick film front contacts on crystalline silicon solar cells," in Proc. 18th Eur. Photovoltaic Sol. Energy Conf., 2002, pp. 343-346.

[11] C. Ballif, D. M. Huljić, G. Willeke, and A. Hessler-Wyser, "Silver thickfilm contacts on highly doped n-type silicon emitters: structural and electronic properties of the interface," Appl. Phys. Lett., vol. 82, no. 12, pp. 1878-1881, 2003.

[12] D. M. Huljić, C. Ballif, A. Hessler-Wyser, and G. Willeke, "Microstructural analyses of Ag thick-film contacts on n-type silicon emitters," in Proc. 3rd World Conf. Photovoltaic Energy Convers., 2003, vol. 1, pp. 83-86.

[13] S. Riegel, F. Mutter, T. Lauermann, B. Terheiden, and G. Hahn, "Review on screen printed metallization on p-type silicon," Energy Procedia, vol. 21, pp. 14-23, 2012.

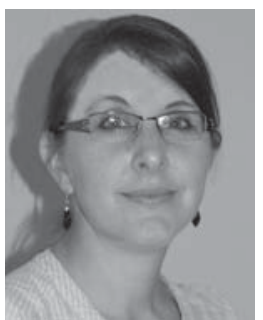

Susanne Fritz was born in Waldshut, Germany. She studied physics with the University of Ulm, Ulm, Germany, and the University of Konstanz, Konstanz, Germany. She received the Diploma degree in physics from the University of Konstanz in 2012, where her focus was set on hydrogen passivation of grain boundaries. She is currently working toward the Ph.D. degree with the Characterization Group of the Photovoltaics Division, University of Konstanz.

Her major research interests include screenprinted metallization of crystalline Si solar cells focusing on the contact formation to $\mathrm{p}^{+} \mathrm{Si}$.

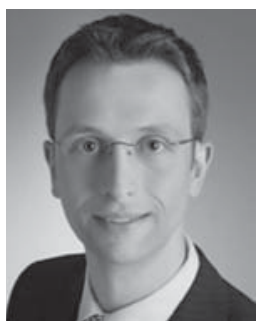

Markus König was born in Lüdenscheid, Germany, in 1981. He received the Diploma degree in materials science from Technische Universität Darmstadt, Darmstadt, Germany, in the field of metal-ceramic compounds in 2006. From 2006 to 2010, he was a $\mathrm{Ph} . \mathrm{D}$. student with an Industry-Joint Laboratory on Printed Electronics, Technische Universität Darmstadt. He received the Ph.D. degree in sintering of nanoscaled zinc oxide particles and thin films from Technische Universität Darmstadt in 2011.

In 2008, he was a Visiting Researcher with the University of New South Wales, Sydney, Australia. Since 2010, he has been with Heraeus Precious Metals GmbH \& Co. KG, Hanau, Germany, working on the development of metallization pastes for silicon solar cells. His research interests include paste rheology, high-temperature processes for contact formation, and solar cell physics.

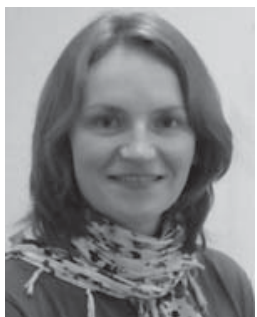

Stefanie Riegel received her final exam (Staatsexamen) in physics and mathematics from the RuprechtKarls-University of Heidelberg, Heidelberg, Germany, in 2006. She is currently working toward the Ph.D. degree with the Industrial Solar Cells Group, Photovoltaics Division, University of Konstanz, Konstanz, Germany.

Her research interests include screen-printed metallization and contact formation of crystalline silicon solar cells.

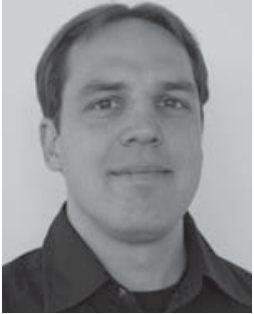

Axel Herguth received the Diploma degree in physics from the University of Konstanz, Konstanz, Germany, in 2006.

Since 2007, he has been the Head of the Characterization Group with the Photovoltaics Division, University of Konstanz. His research interests include the, kinetics of defects in silicon in general especially the kinetics of the metastable boron-oxygen-related defects, as well as characterization techniques for silicon wafers and solar cells.

Mr. Herguth received the Junior Einstein Award from Solarworld in 2006 for his work on the avoidance of the boron-oxygenrelated degradation.

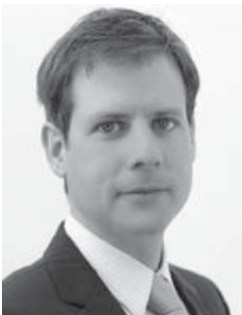

Matthias Hörteis was born in Neumarkt, Germany, in 1976. He studied physics with the University of Augsburg, Augsburg, Germany, and the Australian National University, Canberra, Australia, and received the Diploma degree in 2005. He received the Ph.D. degree from the University of Konstanz, Konstanz, Germany, in 2009.

His career in photovoltaics started in 2005 with the department "Silicon Solar Cells_-Development and Characterization," Fraunhofer ISE, Freiburg, Germany, where he had the opportunity to work as a Scientist with the group of S. Glunz on high-efficiency solar cells. From 2009 to 2011, he managed the group "Metallization Technologies" with Fraunhofer ISE. Since 2011, he has been with Heraeus Precious Metals GmbH \& Co. KG, Hanau, Germany, as an R\&D Manager, where he is responsible for the development of new metallization pastes.

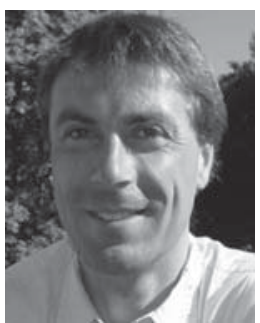

Giso Hahn (M'10) was born in Frankfurt am Main, Germany, in 1969. He received the Diploma degree in physics from the University of Stuttgart, Stuttgart, Germany, in 1995 and the Ph.D. degree in physics from University of Konstanz, Konstanz, Germany, in 1999. He received the Venia Legendi (Habilitation) degree in experimental physics from University of Konstanz in 2005.

Since 2009, he has been an Apl. Professor with the Department of Physics, University of Konstanz. $\mathrm{He}$ is also the Head of the Photovoltaics Division, Department of Physics, University of Konstanz, with around 50 employees. His research interests include crystalline silicon materials and solar cell process development, characterization of promising low-cost materials for photovoltaic applications, and development of adapted solar cell processes for these and other materials. He is the author/coauthor of more than 260 publications in journals, books, and conference proceedings and holds several patents.

Prof. Hahn is a member of the scientific committees of various conference series (e.g., IEEE PVSC, EU PVSEC, and SiliconPV) and workshops. His other scientific and technological achievements include reaching record efficiencies for selected crystalline silicon materials and detailed characterization of efficiency limiting crystal defects. His group is interested in transferring technologies from the laboratory stage to industry. 